\title{
BEHIND TRADE BALANCE SURPLUS IN KALIMANTAN BARAT AMIDST COVID-19 PANDEMIC
}

\author{
Fatmawati* \\ Badan Pusat Statistik Kalimantan Barat, Indonesia
}

\begin{abstract}
This study aims to determine general exports/imports structure, find the commodities and their salient characteristics, and measure changes in primary commodities price during the pandemic in Kalimantan Barat. The data used is Kalimantan Barat's export and import from Statistics Indonesia over January 2019 - June 2021 through descriptive analysis method and Fisher Index unit value. The results explain that three primary export commodities are bauxite, palm oil, and rubber. Bauxite and natural rubber were shocked by the pandemic, but palm oil can still hold. The government encourages downstream activities for bauxite and palm oil to produce value-added products, while rubber pays more attention to upstream quality. The contribution of exports is relatively significant to affect economic growth with the downstream process performed by the government; tremendous added value can be seen in palm oil commodities. Imports are beneficial because they add intermediate materials to support industrial processes. The recommendation is that local governments continue intensive monitoring and evaluation of smelter construction even during the Covid-19 pandemic, concentrate on the grade of palm oil downstream for its sustainability, and improve rubber trading system and capacity building for rubber extension officers to provide adequate guidance to rubber farmers.
\end{abstract}

JEL : F10, F19, F40.

Keywords: trade balance, export, fisher index, downstream, descriptive statistics, covid-19.

\begin{abstract}
ABSTRAK
Penelitian ini bertujuan untuk mengetahui gambaran umum struktur ekspor/impor; mengetahui komoditas utama dan karakteristik yang menonjol; serta mengukur perubahan harga komoditas utama selama pandemi di Kalimantan Barat. Data yang digunakan adalah data ekspor dan impor Kalimantan Barat yang dikumpulkan oleh Badan Pusat Statistik selama periode Januari 2019 - Juli 2021 dengan analisis deskriptif dan Indeks Fisher. Hasil penelitian menjelaskan bahwa neraca perdagangan masih didominasi oleh aktivitas ekspor. Tiga komoditas ekspor utama adalah bauksit, minyak sawit dan karet. Pemerintah mendorong kegiatan hilirisasi pada komoditas bauksit dan kelapa sawit untuk menghasilkan produk bernilai tambah, sementara komoditas karet justru lebih memperhatikan kualitas hulu. Kontribusi ekspor sangat mempengaruhi pertumbuhan ekonomi dengan proses hilirisasi yang dilakukan oleh pemerintah, nilai tambah yang sangat besar terlihat pada komoditas minyak sawit. Aktivitas impor juga sangat menunjang perekonomian, selama impor yang dimanfaatkan adalah bahan baku penolong untuk mendukung proses industri. Oleh karena itu disarankan untuk pemerintah daerah agar tetap melakukan pengawasan dan evaluasi secara intensif berkala terhadap progres pembangunan smelter meskipun di masa pandemi Covid-19, memperhatikan kualitas produk hilir minyak sawit agar dapat terus berkelanjutan, memperbaiki tata niaga karet serta meningkatkan kualitas penyuluh karet agar tepat sasaran dalam melakukan pembinaan kepada petani karet.
\end{abstract}

Kata Kunci : neraca perdagangan, ekspor, indeks fisher, hilirisasi, statistik deskriptif, covid-19.

\section{INTRODUCTION}

Since World Health Organisation officially announced the first occurrence of Covid-19, this pandemic has negatively influenced economic and trade stability globally, including in Indonesia (Olivia, Gibson \& Nasrudin, 2020; Pati, 2020; Sari, 2020; Susilawati, Falefi \& Purwoko,

\footnotetext{
*Email : fatmaw@bps.go.id

Received : 14-09-2021, Accepted : 22-12-2021, Published : 28-12-2021

P-ISSN : 2087-9954, E-ISSN : 2550-0066. DOI : http://dx.doi.org/10.26418/jebik.v10i3.49264
} 
2020). Instability and changes in the world economic chain affect the supply of goods and global trade, eventually forming a new pattern in trade relations between countries (Barua, 2020).

As one of the countries that hold the most significant export activity globally, China significantly influences the pattern of trade between countries (Hidalgo, 2020). One of the countries that often conduct trade activities with China in Indonesia. In addition, China is also one of the largest trading partners in Indonesia. The emergence of Covid-19 that infects China has brought China's trade activities in a negative direction and impacted the flow and the world trade system, including Indonesia (Nasution, Erlina \& Muda, 2020).

Several studies discussing the trade balance and exports and imports have previously been carried out with the following results: economic and trade phenomena are weakening during the Covid-19 pandemic (Thirafi, 2020). The trade balance is influenced by an increase in exports, a decrease in imports, and the foreign trade ratio, which tends to increase (Wulandari \& Lubis, 2019), while exports affect the supply of products available to domestic consumers so that they can affect domestic prices, imports have a positive but significant effect on Indonesia's inflation (Jumhur, Nasrun, Agustiar \& Wahyudi, 2018). The value of imports and exports of non-oil and gas has a significant adverse impact on the volatility of foreign exchange reserves (Asyaria, Budiantoro \& Herianingrum, 2020). The characteristics of trade balance have shown a link to economic growth (Blavasciunaite, Garsviene \& Matuzeviciute, 2020), exports, imports, and economic openness significantly affect Human Development Index (Azzaki, 2021).

Kalimantan Barat is one of the provinces with a positive export value in 2020 compared to 2019, which is 25.01 percent (Kementerian Perdagangan, 2021); with the value of the trade balance always a surplus during the Covid-19 pandemic (BPS, 2021). Indonesia's trade balance surplus shows that the excess occurred because imports fell sharply compared to exports (Jiuhardi, Darma \& Heksarini, 2021). Contrary to that phenomenon, Kalimantan Barat shows an increase in exports and a decrease in the value of imports. These paradoxical phenomena need to be analyzed more to know the underlying ones.

The aims of this research are to 1). Knowing the general description of the structure of exports/imports during the pandemic; 2). Understanding the primary commodities and characteristics that stand out; 3) Measuring changes in the prices of primary commodities before and after the pandemic in Kalimantan Barat. This issue is significant to study because a trade balance surplus or deficit can affect economic growth in a region (Blavasciunaite et al., 2020). The results of this study will be helpful for the Kalimantan Barat local government notice policies that will impact Kalimantan Barat's economic growth and the steps that need to be taken to continue improving Kalimantan Barat's trade balance performance.

\section{LITERATURE REVIEW}

The trade balance is the difference in the value of exports and imports, and the deficit balance means that the value of imports is higher than exports, while the surplus balance has the opposite meaning (Laksono \& Saudi, 2020; Rangkuty, Efendi \& Nasution, 2021). Nationally, Indonesia's export growth was smaller than import growth over the last two decades. Indonesia's exports are dominated by non-oil and gas goods, where the industrial sector is the most dominant, followed by mining and agriculture. In contrast, Indonesia's imports are dominated by raw goods, which are then processed into various commodities distributed to the public. This phenomenon 
shows the dependence of the Indonesian industry on raw materials originating from abroad (Thirafi, 2020). In addition, the manufacturing sector also has a role in the import chain, especially for export-oriented products (Araujo, de Paiva \& Santos, 2019). When the Covid-19 strike, nonoil and gas goods fell, other effects on the manufacturing sector, such as industrial processing, were also felt. So far, the manufacturing industry has made a significant contribution to the Indonesian economy (between 19 and 20 percent), and products originating in the processing industry have contributed roughly 70 percent of Indonesia's total exports. With the increasing number of COVID-19 cases in Indonesia, the performance of the manufacturing industry in Indonesia is likely to slow. The slowdown was caused again because most of Indonesia's manufacturing industries are still dependent on imports from China. This circumstance will significantly impact Indonesia's trade performance in 2020. As a result, Indonesia must seek raw materials or capital goods from other countries, which will be difficult and costly (Nabilla, 2021).

The trade balance, which continues to be in surplus during the Covid-19 pandemic, hides the characteristics of information in the Indonesian economy; therefore, it is necessary to pay attention to the structure of the trade balance and the commodities that play a role. (Rohmi, Jaya \& Syamsiyah, 2021; Trofimov, 2020). The form context in the trade balance surplus refers to sectors and commodities playing significant roles in bringing export or import growth. Thus analyzing the strucsystemcomentitiesr export and import itself is a way to explain the surplus phenomena in trade balance performance.

The four leading price indices, the consumer price index (CPI), the producer price index, and the export and import price indices (XMPI), are well known and closely monitoredmacroeconomic indicators in the economic statistical system. They are a direct indicator of price inflation for the flow of various goods and services. Therefore, it is also used to contract the nominal value of a set of goods and services produced, consumed, and sold to estimate changes in output. These indices are essential tools for designing and implementing government monetary and fiscal policies and valuable for economic decision-making across the private sector. They do not simply contain an unrelated set of price indicators. Still, They provide an integrated and consistent view of price movements related to the production, consumption, and international trade of goods and services. (International Monetary Fund, 2009). For XMPI, based on the consensus of seven international organizations and index number theory, the Fisher index is considered best (Diewert, 2013; McCormack, Thorne \& Hanrahan, 2020).

A study conducted in Turkey using two Fisher price indices was calculated for quantity and customs price to measure the total impact of the COVID-19 phenomenon on Turkey's seafood export trade. The Fisher quantity index and price index showed that the mean values of exported products in quantity and customs value decreased from 2019 to 2020 (Can, Şimşek, Demirci, Demirci1 \& Akar, 2020). Another study calculated the Fisher-price index per exporter and per industry at the standard 3-digit level System of International Trade Classification (SITC). The result showed there were two main patterns in the data. The first pattern was the differentiated Fisher export prices index, which has a positive attitude towards the quality of the facility. The second pattern is that the Fisher export price index and various institutional variables are quite different (Faruq, 2011). 


\section{RESEARCH METHOD}

This study uses quantitative analysis with a descriptive statistical method approach to find out the description of the data structure and the primary commodities of the trade balance. Descriptive statistics are techniques for processing raw data into a more useful form. These techniques include collecting, organizing, summarizing, describing, and displaying numerical information (Bernstein \& Bernstein, 1999). This research uses the following stages: (1) Determine the dominance of international trade activities, (2) Determine the main commodity in the dominant activity with descriptive analysis, (3) Analysis of changes in the price of the main commodity in the dominant activity using the unit value index, (4) Calculating the Laspeyres Index, calculating the Paasche Indeks, and calculating Fisher's Index, (5) Descriptive analysis in general on nondominant trading activities.

Before analyzing the primary commodities between exports and imports, we will determine the dominance of international trade activities between exports and imports using the International Trade Ratio (ITR). ITR shows the magnitude of the difference between the value of exports and the value of imports to the total world trade in a country or region (Wulandari \& Lubis, 2019).

$I T R=\frac{E-I}{T}$

where,

ITR = International Trade Ratio,

$E \quad=$ Eksport,

$I \quad=$ Import,

$T \quad=$ Total Trade (Exports plus Imports).

If the ITR ranges from minus 1 , then international trade is dominated by imports, while if it varies between positive 1 , then international trade is dominated by export transactions.

After knowing the dominance of trading activity, the study will analyze changes in the primary commodity prices before and after the pandemic. Several studies show that price analysis can indicate the quality of a commodity (Mastrobuoni, Peracchi \& Tetenov, 2014); price variations also show profit patterns for business actors (Bentounsi, Agmour, Achtaich \& El Foutayeni, 2018). The price index is an index to measure changes in prices by comparing prices at the time of observation to the base time (Banos \& Vogt, 2013). Based on manual work on the Export and Import Price Index (XMPI) done in collaboration with the International Labor Organization (ILO), the International Monetary Fund (IMF), the Organization for Economic Cooperation and Development (OECD), the Statistics Office of the European Community (Eurostat), the United Nations Economic Commission for Europe (UNECE), and the World Bank, as well as experts from several national statistical offices, countries, universities, and other international organizations, there is now a significant consensus among economists and XMPI compilers as to which type of formula is most appropriate to use, at least in principle.

Although the agreement does not deal with a single formula, it reduces to a small class of superlative indices. Diewert, through the economic approach, described an index number formula to be superlative if it is equal to a theoretical price index whose functional form is flexible. The three commonly used excellent indices are Fisher, Walsh, and Törnqvist. The Fisher index is the geometric mean of the Laspeyres and Paasche indices; this index utilizes prices and quantities 
equally in their weights. This index complies with the time-reversal test and is considered "best" at the fixed basket approach (Diewert, 2013).

$F I=\sqrt{L I \times P I}$

Laspeyres and Paasche develop an index price formula through the fixed basket approach. Laspeyres proposed a price index using a weighing quantity based on the base year to eliminate price variations.

$L I=\frac{\sum p_{t} q_{0}}{\sum p_{0} q_{0}}$

Meanwhile, Paasche proposed an index figure that uses the quantity in the current year as its weight.

$P I=\frac{\sum p_{t} q_{t}}{\sum p_{0} q_{t}}$

However, both indexes fail to satisfy the time-reversal saltates that if the prices and quantities in the two periods being compared are swapped, the resulting price index is the inverse of the original price index. While the Fisher index passes about 21 "reasonable" tests using the test approach, the Fisher index is also one of the most considered formulas through the economic system. Therefore, the Fisher index is best through three approaches to index number theory (Diewert, 2013; McCormack et al., 2020). Because the available data are monthly, the adjustment of the Fisher index calculation with the unit value approach for the annual index with one commodity will be multiplied by weights, resulting in the following formula (BPS, 2021).

$F I=\sum(\sqrt{L I \times P I}) \times w$

where,

$F I=$ Fisher Index,

$L I=$ Laspeyres Index,

$P I=$ Indeks Paasche,

$p_{t}=$ Unit Value in the period after the pandemic (2020-2021),

$p_{0}=$ Unit Value in the base year period/before the pandemic (2019),

$q_{t}=$ Quantity in the period of the year after the pandemic (2020-2021),

$q_{0}=$ Quantity in the base year period/before the pandemic (2019),

$w=$ The role of commodities per month to total entities a year.

The data available in this study is the value and weight of export and import activities. Value is the product of price and quantity; using The Fisher Index approach, we can calculate the price index from value data (Cross \& Färe, 2015). We can get the unit value by dividing the value by its quantity. Using the Fisher Index, changes in the prices of primary commodities will be calculated on the dominance of trading activities in Kalimantan Barat during the Covid-19 pandemic using 2019 as the base year because there has not been a pandemic at this year.

The source of data in this study uses export and import data collected by Statistics Indonesia (BPS). For export data, BPS gathers data on the value and weight of export commodities monthly based on the Export Declaration of Goods (PEB) and non-PEB documents. The exporter filled out the PEB document and was given a loading permit by the Customs and Excise Service Office, then sent to BPS and Bank Indonesia (BI). Meanwhile, non-PEB documents sourced from 
records from other agencies export data from PT. POS Indonesia, and data from export surveys at several Indonesian sea borders. Import statistics are collected based on import documents Notice on Import of Goods (PIB - BC 2.0), Notification of Transport of Imported Goods (PPBI-BC 2.3), Notification of Import of Special Goods (PIBK-BC 2.1), and Notification of Customs Free Trade Zone (PPFTZ) which filled in by importer. PIB-BC 2.0 and PPBI-BC 2.3 documents received from Customs and Excise and valid since April 1997 based on the Minister of Finance number 101/KMK.05/1997 dated March 10, 1997. The data used is from January 2019 to July 2021 and is limited only to Kalimantan Barat's port transactions.

\section{RESULTS AND DISCUSSION}

\subsection{Exports, Imports, and the Economy}

The process of export diversification through the manufacturing industry is very influential on economic growth (Belkania, 2020); therefore, the government is trying to increase exports of goods by exporting value-added products from the downstream process, such as bauxite and palm oil in Kalimantan Barat. Palm oil exports give an immense added value through its diversification of commodities. Consequently, the contribution of Kalimantan Barat's exports is relatively significant to affect economic growth with the government's downstream process. The increase in exports can be seen in the gift of exports to GRDP compared to 2019.



Source: Statistics Indonesia

Figure 1. Export Contribution Development in Kalimantan Barat 2019-2021

Import activity shows economic strength (Rahman \& Dilanchiev, 2021). The increase in export commodities for downstream products is inseparable from the role of the government has made a policy to facilitate the import of intermediate goods to support industrial processes (Wildan, Freycinetia, Khadafi \& Azka, 2020), especially during the Covid-19 pandemic. Intermediate goods are raw materials used for other production processes (Paul \& Barua, 2021; Tampubolon \& Nababan, 2018). In Kalimantan Barat itself, imports of intermediate goods are still dominant, which is intended to help increase the added value of goods exports to international markets. 


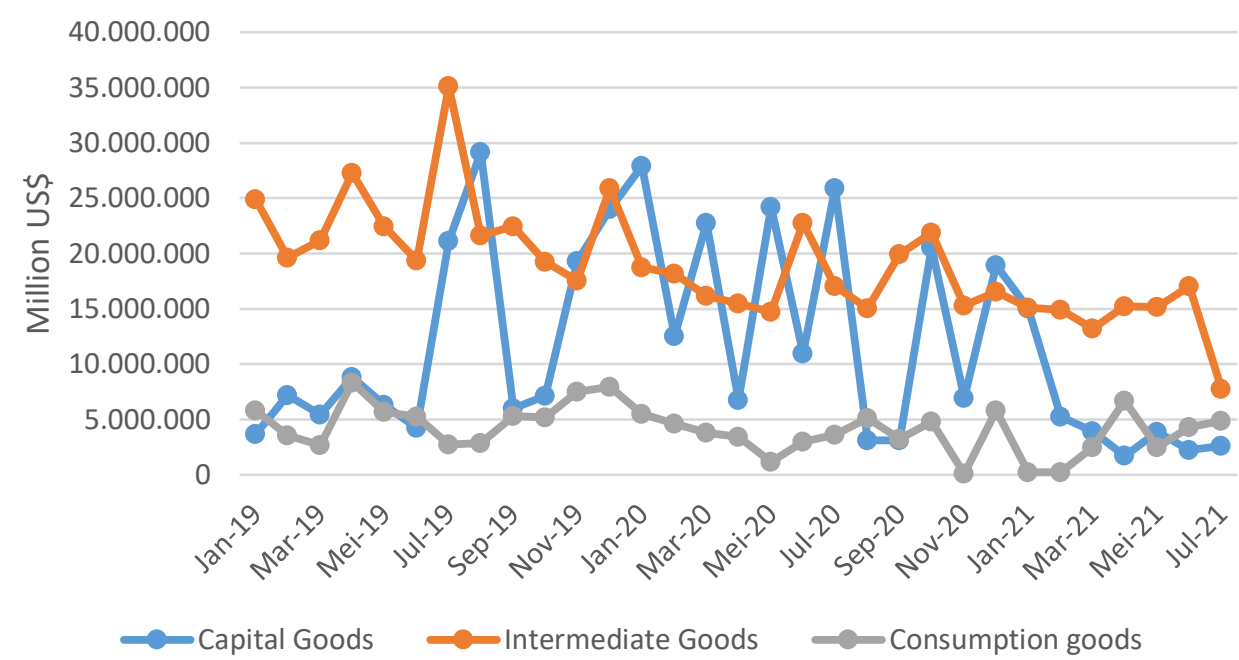

Figure 2. Imports by Type of Goods in Kalimantan Barat Jan 2019 - July 2021

\subsection{Main Commodity Export}

Figure 3. shows that the ITR is in the range of positive 1, so the dominant trading activity in Kalimantan Barat during the Covid-19 pandemic was export activity. The dominance of export activity, empirically, has been proven to significantly increase the trade balance (Tran, Nguyen, Nguyen \& $\mathrm{Vu}, 2020$ ), so it is essential to compare the primary commodities that affect export activity before and after the Covid-19 pandemic. Export activity during January 2020 - July 2021 amounted to 85.07 percent consisting of 3 primary commodities, namely bauxite (57,21 percent), palm oil ( 19,83 percent), and natural rubber $(8,03$ percent).

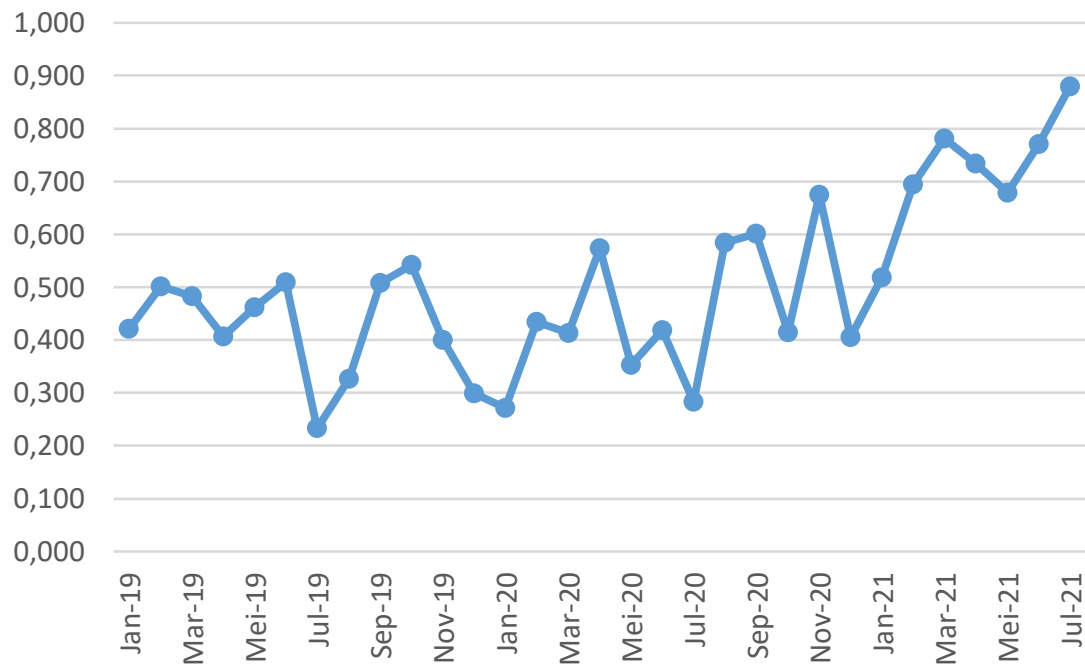

Figure 3. Kalimantan Barat's International Trade Ratio January 2019-July 2021

Bauxite is the primary ore of alumina (A12O3) producing aluminum (Al), which is composed of hydrated aluminium oxide, hydrated aluminosilicate, iron oxide, hydrated iron oxide, titanium oxide, and silica (Donoghue, Frisch \& Olney, 2014). Bauxite is one of the mainstay commodities and a driver of economic growth in Kalimantan Barat. Bauxite can also be used as a center of economic growth in Kalimantan Barat within the framework of the Master Plan for the 
Percepatan dan Perluasan Pembangunan Ekonomi Indonesia (MP3EI). This approach is essentially an integration of sectoral and regional policies. The development of centers of economic growth is carried out in an integrated manner so that it is expected to provide direct and indirect benefits to other economic sectors in the region through the mechanism of socio-economic linkages (Suherman, Suseno \& Saleh, 2015).

The government has issued various policies to maximize bauxite commodities to provide added value and develop the domestic industry downstream. Law No. 3 of 2020 mandates that bauxite entrepreneurs no longer export raw materials (Pribadi, 2020). However, the government gave a relaxing metal mineral exports policy to deal with the Covid-19 pandemic, which was issued on March 12, 2021, in Ministerial Decree (Kepmen) ESDM No. 46/K/MB.04/MEM.B/2021. This relaxation policy gives holders of Mining Business Permits (IUP). Special Mining Business Permits (IUPK) for Metal Mineral Production Operations can still be given export approval recommendations valid for one year, even though the related IUP and IUPK do not meet the percentage of physical progress smelter construction (Ahda, 2021).

Table 1. Fisher Unit Value Index of Main Commodity Export in Kalimantan Barat 2020-2021

\begin{tabular}{lcr}
\hline \multicolumn{1}{c}{ Export Commodities } & $\mathbf{2 0 2 0}$ & $\mathbf{2 0 2 1} *$ \\
\hline Bauxite: & & \\
Aluminum Ore & 95.43 & 102.57 \\
Alumina & 80.37 & 75.67 \\
Palm Oil & 144.80 & 212.20 \\
Natural Rubber & 97.39 & 120.23 \\
*July 2021 & &
\end{tabular}

Bauxite exports in Kalimantan Barat during the Covid-19 pandemic were still dominated by aluminium ore and tended to increase. In contrast, the bauxite processing industry into alumina (aluminium oxide) tended to decline. Fisher's index for aluminium ore commodities shows an average change in prices compared to 2019, respectively $-4,57 \%$ in 2020 and an increase of 2,57\% in 2021. For alumina commodities, the average price declines compared to 2019, respectively $19,63 \%$ in 2020 and $-24,33 \%$ in 2021 . This index shows that in 2020 both aluminium ores and alumina suffered a shock from the pandemic through price decline. China is the only destination country for aluminium ores, while India, Malaysia, China, Vietnam, and Thailand are aluminum oxide destinations. It can also be noted that Indonesia's export share is mainly to China which reached $28,22 \%$, then the United States (US) $11,14 \%$, and then Japan 6,73\%.

For minerals, processing downstream of the ore or concentrate stage usually includes weight savings. In theory, the lower shipping cost should be robust, like 3/4 for bauxite/aluminum. Some interpret that if downstream products fail in the market, the playing field is not flat in many cases. It is important to note that, unlike industrial products, branding, market segmentation, service connections, and quality differences play a small role in the mineral and metals market. As a result, it lacks the characteristics that are the root cause of market failure. Few questions arise about how processed products from mining countries achieve sufficient profitability at the stage of processing and marketing, rather than being competitive in the global market (Östensson, 2019).

Alumina products that experience a price decline from unit value index data accompanied by a decrease in production (Ruswana, Ma'arif \& Kirbrandoko, 2020) need to get attention from the government for the sustainability of the bauxite downstream process after the pandemic. Later, it is hoped that this process will increase added value (Fauzi \& Harto, 2017), the availability of raw materials for the domestic downstream industry of alumina, and mastery of technology in 
alumina processing (Wikarya, 2019). On the other hand, the export ban or downstream policies must be accompanied by providing transportation infrastructure and electrical energy (Liun \& Nurlaila, 2021; Östensson, 2019). Periodic intensive technical and financial monitoring and evaluation of the smelter construction progress must also be carried out even during the pandemic. Increasing the absorption of domestic production also needs to be one of the points for optimizing the completed smelter (Ahda, 2021; Suparji \& Mizi, 2019).

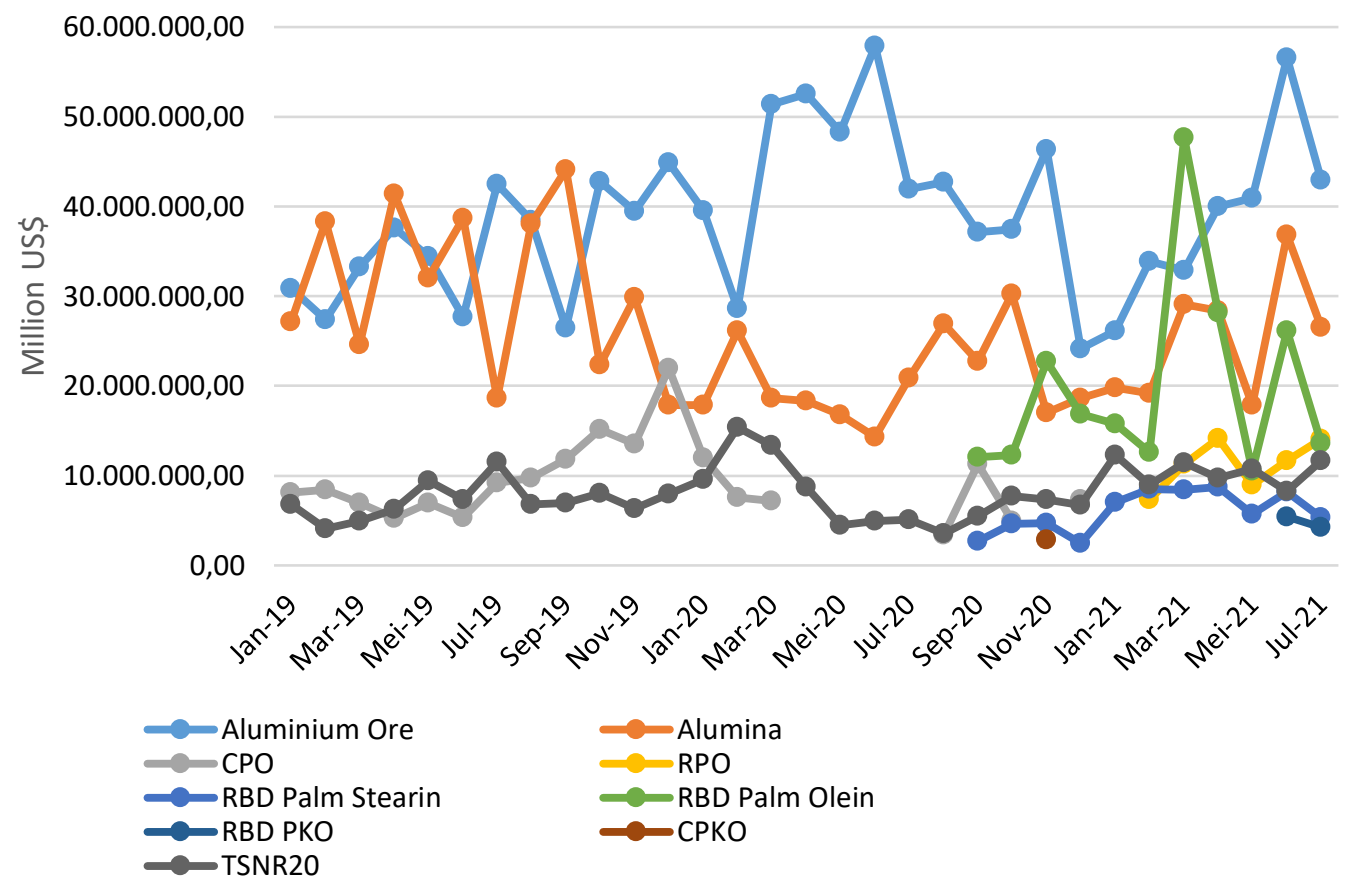

Figure 4. Main Commodity Export Trend in Kalimantan Barat January 2019-July 2021 *) $\mathrm{RPO}=$ Refined Palm Oil, RBD Palm Stearin $=$ Refined Bleached Deodorized Palm Stearin, CPKO = Crude Palm Kernel Oil, RBD PKO = Refined Bleached Deodorized Palm Kernel Oil, TSNR20 = Natural Rubber.

The palm oil industry has an essential and strategic role in the Indonesian economy. It is a foreign exchange earner for Indonesia and a driving force for the people's economy to absorb much labor. Oil palm thrives in Indonesia, which is a tropical region, where oil palm plantations are spread across almost all the islands in Indonesia. 22 out of 34 provinces in Indonesia have succeeded in developing oil palm plantations, of which around 90 percent are on the islands of Sumatra and Kalimantan. As centers of oil palm plantations in Indonesia, the two islands can produce 95 percent of crude palm oil (CPO). The high demand for CPO as an industrial raw material and the increased production and processing of Indonesian CPO are the driving factors for Indonesia to export this commodity worldwide (Irawan \& Soesilo, 2021).

According to the Ministry of Industry, the palm oil industry consists of oil palm meat and oil palm seeds. Palm oil meat will produce palm oil (Crude Palm Oil / CPO), while oil palm seeds will produce palm kernel oil (Palm Kernel Oil / PKO). Ministry of Agriculture estimates that in 2021, Kalimantan Barat has the most significant area and production among other Kalimantan provinces, with 70,50 percent of the scope belonging to the private, 28,15 percent to smallholders, and 1,35 percent to government estate. 
Compared to 2019, the change in palm oil prices is very encouraging; the value is $44,80 \%$ in 2020 and $112,20 \%$ in 2021. The index shows that palm oil can hold on through pandemics, seeing the price increase despite pandemics. If we look more deeply, palm oil exports experience changes in their export commodities. Downstream products began to be exported at the end of 2020, namely derivative products from palm oil, Refined Bleached Deodorized Palm Olein or better known as RBD Palm Olein, which caused a substantial change in unit value due to the added value obtained (Suryono, 2019). RBD Palm Olein commodity's very high export value significantly affects Kalimantan Barat's trade balance, even bringing a trade balance surplus to a relatively high point in March 2021. RBD Palm Olein is a palm oil derivative product that has gone through a screening process and is a raw material for cooking oil and the food industry. With a relatively good level of competition, in the future, the utilization of downstream palm oil products is not only for export but also for the needs of the domestic industry (Arsyad, Amiruddin, Suharno \& Jahroh, 2020).

There are three pathways for downstream CPO in Indonesia, which is the government's main focus, namely through downstream ole food processing CPO into food products, such as oil fry, butter, fodder, and ice cream creamer, and others. The second path is downstream oleochemicals that process CPO into laundry soap, bath soap, shampoo, cosmetics, etc. The third pathway is biofuel downstream, processing CPO into biofuels, such as biodiesel, biogas, bioavtur, and bio premium. Downstream is the main focus for the palm oil industry, and it is a multi-product industry integrated. With the establishment of a policy, there are great opportunities in the Indonesian CPO market. Therefore the government's hope is that output/production in downstream industries increases, which is indicated by the increasing consumption of CPO as the primary raw material for downstream industrial products. It is hoped that with the downstream program, the palm oil industry will impact increased investment that will bring improvements in technology and new knowledge to increase production (Irawan \& Soesilo, 2021).

Rubber is one of Indonesia's leading export commodities that positively contribute to the economy (Daulika, Peng \& Hanani, 2020) and has a competitive advantage (Lindung \& Jamil, 2018). As one of the largest rubber-producing countries globally, Indonesia has the ten largest rubber-producing provinces, which are Bengkulu, Sumatera Barat, Kalimantan Tengah, Lampung, Kalimantan Selatan, Kalimantan Barat, Jambi, Riau, Sumatera Utara and Sumatera Selatan. (Hertina, Nisyak \& Supli, 2021). According to estimation Ministry of Agriculture (Gartina \& Sukriya, 2020), in 2021, the Kalimantan Barat area, production, and farmers, is the largest among other Kaliman provinces but in the bottom of two for productivity.

Since 2017 the price of rubber has been very volatile because natural rubber production tends to exceed market demand so that the stock is abundant and causes prices to fall. Facing this, the Indonesian government, Malaysia, and the Thailand International Tripartite Rubber Council (ITRC) agreed to reduce rubber exports to increase rubber prices (Perdana, 2020). The policy benefited rubber farmers; this was proven by an increase in rubber export prices (Purwaninngrat, Novianti \& Dermoredjo, 2020).

The Fisher unit value index shows that changes in natural rubber prices in 2020 and 2021 are $-2.61 \%$ and $20.23 \%$, respectively. We can see that natural rubber suffered pandemic shock during 2020 but can recover in 2021. During the Covid-19 pandemic, the opportunity to use natural rubber was tremendous for functional medical properties made from natural rubber, such as gloves, oxygen hoses, footwear, drug packaging, and tires (Wallace \& Horner, 2020). 
Local government efforts are needed in improving the marketing of natural rubber, which will ultimately improve the welfare of farmers (Ramadhan \& Sulasmiyati, 2020). Efforts made by local governments are to improve the trading system, which incorporates all stakeholders; guidance from the upstream side, in the form of assistance to farmers such as fertilizers or equipment and reactivation plantation extension workers (Bayurini, 2020). Data from the Department of Agriculture and Animal Husbandry Kalimantan Barat 2021 shows that only 11 UPPB (Unit Pengolahan dan Pemasaran Bokar-Bahan Olah Karet) registered, but only two functioning. This unit amount is barely enough to cover the rubber plantation sector. Therefore it is essential to increase the UPPB size.

Research for the extension worker side shows that the extension workers significantly influence farmer empowerment in achieving extension goals (Rosnita, Sayamar, Sianturi, Yulid \& Simanjuntak, 2017). However, the quality of extension workers' roles should be increased to achieve extension goals (Taufik, Rosnita' \& Sayamar, 2016). The policy regarding the trading system is in line with several previous studies, namely the supply chain network through the farmer-UPPB-factory pattern, which cut down the supply chain and distribution price and eventually encouraged farmers to produce higher quality crumb rubber raw materials so that the price is higher than it used to (Herdiansyah, Nurmalina \& Winandi, 2015; Nugraha, Alamsyah \& Sahuri, 2018; Suharyon, 2021).

\section{CONCLUSIONS AND RECOMMENDATIONS}

From the results and discussion above, we can conclude that export activities still dominate the trade balance. The three primary export commodities are bauxite, palm oil, and rubber. In 2020, the Fisher Index showed that bauxite and natural rubber were shocked by the pandemic, but palm oil can still hold. The government encourages downstream activities for bauxite and palm oil commodities to produce value-added products, while rubber commodities pay more attention to upstream quality. The contribution of Kalimantan Barat's exports is relatively significant to affect economic growth with the government's downstream process. In addition to exports, import activities also support the economy by importing intermediate goods to support industrial processes.

Recommendations from the discussion above are to continue intensive monitoring and periodic evaluation of the progress of smelter construction even during the Covid-19 pandemic. Pay attention to the quality of downstream palm oil products to be sustainable, improve the rubber trading system through the UPPB, and improve the quality of rubber extension workers so that they are right on target in providing training to rubber farmers. This study is limited only to the general description. The added value of palm oil contribution to people's welfare for the following research should be conducted. Another limitation is that the exports data are only for transactions in Kalimantan Barat. At the same time, some commodities come from Kalimantan Barat but are exported from other ports or airports. Therefore the subsequent study should be done using the exports origin commodities data.

\section{REFERENCES}

Ahda, N. (2021). Di Balik Kebijakan Relaksasi Ekspor dan Hilirisasi Mineral Logam. Buletin APBN, VI(10), 8-11. 
Araujo, R. A., de Paiva, M. S., \& Santos, J. F. C. (2019). The role of intermediate inputs in a multisectoral balance-of-payments-constrained growth model: the case of Mexico. Journal of Economic Structures, 8(23).

Arsyad, M., Amiruddin, A., Suharno, \& Jahroh, S. (2020). Competitiveness of Palm Oil Products in International Trade: An Analysis between Indonesia and Malaysia. Caraka Tani: Journal of Sustainable Agriculture, 35(2), 157-167.

Asyaria, K., Budiantoro, R. A., \& Herianingrum, S. (2020). Analisis Neraca Perdagangan Migas dan Non Migas Terhadap Volatilitas Cadangan Devisa Di Indonesia, 1975-2016. Jurnal Manajemen Dan Bisnis Indonesia, 6(1), 38-45.

Azzaki, M. A. (2021). Pengaruh Perdagangan Internasional, dan Keterbukaan Ekonomi Terhadap Indeks Pembangunan Manusia di Negara-Negara ASEAN. Jurnal Ekonomi Bisnis Dan Kewirausahaan, 10(2), 154-174.

Banos, J., \& Vogt, A. (2013). The Making of Tests for Index Numbers: Mathematical Methods of Descriptive Statistics. Springer Science \& Business Media.

Barua, S. (2020). COVID-19 Pandemic and World Trade: Some Analytical Notes. SSRN Electronic Journal.

Bayurini, D. (2020). Sekretaris Daerah Menghadiri Penandatanganan Kesepakatan (MOU) PT. New Kalbar Processor. Retrieved October 23, 2021, from Pemerintah Provinsi Kalimantan Barat website: https://kalbarprov.go.id/berita/sekretaris-daerah-menghadiripenandatanganan-kesepakatan-mou-pt-new-kalbar-processor.html

Belkania, D. (2020). Export Structure and Economic Performance in Transition Economies. European Research Studies Journal, XXIII(1), 476-490.

Bentounsi, M., Agmour, I., Achtaich, N., \& El Foutayeni, Y. (2018). The Impact of Price on the Profits of Fishermen Exploiting Tritrophic Prey-Predator Fish Populations. International Journal of Differential Equations, 2018, 1-13.

Bernstein, S., \& Bernstein, R. (1999). Schaum's Outline of Elements of Statistics I: Descriptive Statistics and Probability. McGraw Hill Professional.

Blavasciunaite, D., Garsviene, L., \& Matuzeviciute, K. (2020). Trade balance effects on economic growth: Evidence from european union countries. Economies, 8(54), 1-15.

BPS. (2021). Indeks Unit Value Ekspor Menurut Kode SITC Mei 2021. Jakarta: Badan Pusat Statistik.

Can, M. F., Şimşek, E., Demirci, A., Demirci1, S., \& Akar, Ö. (2020). The evaluation of the early impacts of the COVID-19 pandemic on the export of fishery commodities of Turkey. Marine Life Science, 2(1), 18-27.

Cross, R. M., \& Färe, R. (2015). Value Data and the Fisher Index. Theoretical Economics Letters, 05(02), 262-267.

Daulika, P., Peng, K.-C., \& Hanani, N. (2020). Analysis on Export Competitiveness and Factors Affecting of Natural Rubber Export Price in Indonesia. Agricultural Social Economic Journal, 20(1), 39-44.

Diewert, E. (2013). Irving fisher and index number theory. Journal of the History of Economic Thought, Vol. 35, pp. 199-232.

Donoghue, A. M., Frisch, N., \& Olney, D. (2014). Bauxite mining and alumina refining: Process description and occupational health risks. Journal of Occupational and Environmental Medicine, 56(55), S12-S17. 
Faruq, H. (2011). How institutions affect export quality. Economic Systems, 35(4), 586-606.

Fauzi, A., \& Harto, S. (2017). Motivasi Indonesia Menghentikan Ekspor Mineral Mentah Jenis Bauksit ke Tiongkok Pasca Pemberlakuan Undang-Undang Minerba No.4 Tahun 2009. JOM FISIP, 4(2), 1-15.

Gartina, D., \& Sukriya, R. L. L. (Eds.). (2020). Statistik Perkebunan Unggulan Nasional 20192021. Jakarta: Kementerian Pertanian.

Herdiansyah, R., Nurmalina, R., \& Winandi, R. (2015). Peningkatan Kinerja Pemasaran Karet Alam Rakyat melalui Optimalisasi Rantai Pasok. Jurnal Tanaman Industri Dan Penyegar, 2(3), 151-158.

Hertina, S., Nisyak, K., \& Supli, N. A. (2021). Daya Saing Karet Alam Sumatera Selatan Dalam Perdagangan Internasional. Indonesian Journal of International Relations, 5(2), 241-263.

Hidalgo, C. A. (2020). How Covid-19 has affected trade, in 8 charts. Retrieved October 23, 2021, from World Economic Forum website: https://www.weforum.org/agenda/2020/11/howcovid-19-has-reshuffled-international-trade/

International Monetary Fund. (2009). Export and Import Price Index Manual: Theory and Practice. Washington, DC: International Monetary Fund.

Irawan, B., \& Soesilo, N. I. (2021). Dampak Kebijakan Hilirisasi Industri Kelapa Sawit terhadap Permintaan CPO pada Industri Hilir. Jurnal Ekonomi \& Kebijakan Publik, 12(1), 29-43.

Jiuhardi, Darma, D. C., \& Heksarini, A. (2021). The Political-Economy Management: Indonesia's needs for the covid-19 pandemic. Problems of Management in the 21st Century, 16(1), $19-27$.

Jumhur, Nasrun, M. A., Agustiar, M., \& Wahyudi, W. (2018). Pengaruh Jumlah Uang Beredar, Ekspor dan Impor Terhadap Inflasi (Studi Empiris Pada Perekonomian Indonesia). Jurnal Ekonomi Bisnis Dan Kewirausahaan, 7(3), 186-201.

Kementerian Perdagangan. (2021). Perkembangan Ekspor NonMigas (Provinsi Asal Barang). Jakarta. Retrieved from https://satudata.kemendag.go.id/growth-of-non-oil-and-gasexport-provincial

Laksono, R. ., \& Saudi, M. H. M. (2020). Analysis of the Factors Affecting Trade Balance in Indonesia. International Journal of Psychosocial Rehabilitation, 24(2), 3113-3120.

Lindung, \& Jamil, A. S. (2018). Posisi Daya Saing dan Tingkat Konsentrasi Pasar Ekspor Karet Alam Indonesia di Pasar Global. Jurnal AGRISEP : Kajian Masalah Sosial Ekonomi Pertanian Dan Agribisnis, 17(2), 119-128.

Liun, E., \& Nurlaila, N. (2021). Kebutuhan Energi Untuk Pengolahan Bauksit di Kalimantan Barat. Jurnal Pengembangan Energi Nuklir, 23(1), 29-37.

Mastrobuoni, G., Peracchi, F., \& Tetenov, A. (2014). Price as a Signal of Product Quality: Some Experimental Evidence. Journal of Wine Economics, 9(2), 135-152.

McCormack, M., Thorne, F., \& Hanrahan, K. (2020). Measuring total factor productivity on Irish dairy farms: a Fisher index approach using farm-level data. Irish Journal of Agricultural and Food Research, 59(1), 123-139.

Nabilla, N. (2021). Strategi Diplomasi Ekonomi Indonesia dalam Menjaga Stabilitas Neraca Perdagangan di Tengah Pandemi Covid-19. Jurnal Sosial Politik, 7(2), 227-239.

Nasution, D. A. D., Erlina, E., \& Muda, I. (2020). Dampak Pandemi COVID-19 terhadap Perekonomian Indonesia. Jurnal Benefita, 5(2), 212-224. 
Nugraha, I. S., Alamsyah, A., \& Sahuri, S. (2018). Effort to increase rubber farmers' income when rubber low prices. Jurnal Perspektif Pembiayaan Dan Pembangunan Daerah, 6(3), 345352.

Olivia, S., Gibson, J., \& Nasrudin, R. (2020). Indonesia in the Time of Covid-19. Bulletin of Indonesian Economic Studies, 56(2), 143-174.

Östensson, O. (2019). Promoting downstream processing: resource nationalism or industrial policy? Mineral Economics, 32, 205-212.

Pati, U. K. (2020). Indonesian Government Policy in Mitigating Economic Risks due to the Impact of the Covid-19 Outbreak. Journal of Law and Legal Reform, 1(4), 577-590.

Paul, A., \& Barua, A. (2021). Integrating Trade and Disintegrating Production in Manufacturing Industries: Evidence from APEC and EU Nations. International Journal Business and Economy, 6(1), 97-118.

Perdana, R. P. (2020). Kinerja Ekonomi Karet dan Strategi Pengembangan Hilirisasinya di Indonesia. Forum Penelitian Agro Ekonomi, 37(1), 25-39.

Pribadi, A. (2020). Hilirisasi, Kunci Pemanfaatan Hasil Tambang yang Optimal. Retrieved October 10, 2021, from Kementerian Energi dan Sumber Daya Mineral RI website: https://www.esdm.go.id/id/media-center/arsip-berita/hilirisasi-kunci-pemanfaatan-hasiltambang-yang-optimal

Purwaninngrat, L., Novianti, T., \& Dermoredjo, S. (2020). Dampak Kebijakan International Tripartite Rubber Council (ITRC) terhadap Kesejahteraan Petani Karet Indonesia. Jurnal Ekonomi Pertanian Dan Agribisnis, 4(2), 411-424.

Rahman, M. H., \& Dilanchiev, A. (2021). Does Current Account Increase the Economic Growth in Bangladesh? The Analysis of GMM Technique. European Online Journal of Natural and Social Sciences, 10(1), 52-69.

Ramadhan, M. Y., \& Sulasmiyati, S. (2020). Analisis Perbedaan Harga Karet Alam Dunia dan Ekspor Karet Alam Indonesia Sebelum dan Sesudah Kebijakan Agreed Export Tonnage Scheme (AETS) (Studi Pada Negara Amerika Serikat, Jepang, dan China Periode Mei 2015 - Desember 2016). Jurnal Administrasi Bisnis, 78(1), 156-165.

Rangkuty, D. M., Efendi, B., \& Nasution, L. N. (2021). Study of Indonesia's international macroeconomic indicators before and during the covid-19 pandemic. Jurnal Riset Pendidikan Ekonomi, 6(1), 1-11.

Rohmi, M. L., Jaya, T. J., \& Syamsiyah, N. (2021). The Effects Pandemic Covid-19 on Indonesia Foreign Trade. Jurnal Ekonomi, XXVI(02), 267-279.

Rosnita, Sayamar, E., Sianturi, S. S., Yulid, R., \& Simanjuntak, E. K. . (2017). Analisis Penyuluhan dan Keberdayaan Petani Karet Pola Swadaya di Kabupaten Rokan Hilir, Provinsi Riau. Jurnal Penyuluhan, 13(2), 231-243.

Ruswana, Ma'arif, M. S., \& Kirbrandoko. (2020). Kebijakan Strategis PT. Aneka Tambang Tbk. Jurnal Aplikasi Bisnis Dan Manajemen, 6(3), 602-618.

Sari, D. (2020). Fenomena Ekonomi Dan Perdagangan Indonesia Di Masa Pandemi Corona Virus Disease-19 ( Covid-19 ). AKTIVA Jurnal Akuntansi Dan Investasi, 4(1), 81-93.

Suharyon. (2021). Potensi, Kendala dan Solusi Peremajaan Karet Dalam Mewujudkan Pertanian Maju Mandiri-Modern di Tengah Perubahan Iklim dan Pandemi Covid 19 Di Provinsi Jambi. Jurnal Ilmiah Ilmu Terapan Universitas Jambi|JIITUJ|, 5(1), 48-56. 
Suherman, I., Suseno, T., \& Saleh, R. (2015). Kajian Manfaat Usaha Pertambangan Bauksit Terhadap Sosial Ekonomi Daerah di Provinsi Kalimantan Barat. Jurnal Teknologi Mineral Dan Batubara, 11(2), 129-145.

Suparji, \& Mizi, R. (2019). Penataan Regulasi Mineral dan Batubara Untuk Kesejahteraan Rakyat. Jurnal Magister Ilmu Hukum, 4(2), 1-8.

Suryono, A. (2019). Analisis ekspor indonesia ke negara tujuan utama dan komoditi utama tahun 2013 sampai 2017. Akuntabel, 16(1), 25-30.

Susilawati, S., Falefi, R., \& Purwoko, A. (2020). Impact of COVID-19's Pandemic on the Economy of Indonesia. Budapest International Research and Critics Institute-Journal (BIRCI-Journal), 3(2), 1147-1156.

Tampubolon, J., \& Nababan, T. S. (2018). International Trade and North-Sumatra's Local Economy. JEJAK, 11(2), 323-337.

Taufik, A., Rosnita', \& Sayamar, E. (2016). Peran Penyuluhan Terhadap Petani Karet Pola Swadaya di Kecamatan Peranap Kabupaten Indragiri Hulu. Jom Faperta, 3(1).

Thirafi, L. (2020). Dua Dekade Terakhir Neraca Perdagangan Indonesia. Jurnal Ekonomi Dan Pendidikan, 17(2), 70-82.

Tran, T. N., Nguyen, T. T., Nguyen, V. C., \& Vu, T. T. H. (2020). Energy consumption, economic growth and trade balance in East Asia: A panel data approach. International Journal of Energy Economics and Policy, 10(4), 443-449.

Trofimov, I. D. (2020). The J-curve Effect in Agricultural Commodity Trade: An Empirical Study of South East Asian Economies. MPRA Paper.

Wallace, J., \& Horner, W. (2020, November 11). Rubber Prices Bounce Back, Fueled by Automotive, Medical Demand. WSJ. Retrieved from https://www.wsj.com/articles/rubber-prices-bounce-back-fueled-by-automotive-medicaldemand-11605093577

Wikarya, U. (2019). Efektifitas Kebijakan Hilirisasi Minerba,dan Transparansi Tatakelola. Jakarta.

Wildan, M., Freycinetia, F., Khadafi, M., \& Azka, R. M. (2020). Bahan Baku Jadi Prioritas. Bisnis Indonesia. Retrieved from https://kemenperin.go.id/artikel/21587/Bahan-Baku-JadiPrioritas

Wulandari, S., \& Lubis, A. S. (2019). Analisis Perkembangan Ekspor Impor Barang Ekonomi di Provinsi Sumatera Utara. Jurnal Administrasi Bisnis, 8(1), 31-36. 